\begin{tabular}{|c|c|c|}
\hline & $\begin{array}{c}\text { Mansoura University } \\
\text { Faculty of Engineering } \\
\text { Mansoura Engineering Journal }\end{array}$ & 0.00 \\
\hline
\end{tabular}

\title{
A Comparative Study of the different remote sensing techniques for evaluating land use/ cover in Basra city, Iraq.
}

\author{
Elmwafi, M., Zarzoura, F. and. Jumaah, Z.
}

\author{
KEYWORDS: \\ Land use/ cover, \\ Land degradation, \\ Remote sensing, \\ image classification, \\ Land surface temperature \\ Basra city.
}

Abstract- Basra governorate represents one of the most important
governorates in Iraq, where it is the only seaport for exporting oil and
agriculture products. However, this governorate is facing serious land
degradation problems results in major changes in land use/ cover (LULC)
within the area. Accordingly, the main objective of this study was to evaluate
LULC in Basra city using different techniques on remotely sensed data. For
that purpose, Landsat 8, Sentinel 2 A images were used in 2018 to study extent
of urban areas, agricultural lands, water bodies and bare lands areas in Basra
city center. The studied techniques include: the supervised classification in
three methods (minimum distance, maximum likelihood, and Mahalanobis
distance), spectral indices, manual digitizing of features and land surface
temperature (LST). These methods were applied on both Sentinel 2 A and
Landsat data at three spatial resolutions 10 , 15 and 30 m, respectively. The
obtained results indicated that the minimum distance technique has the
highest accuracy in identifying LULC when compared with the other
classification methods. It was found that the higher the spatial resolution the
higher the accuracy of the results. The spectral indices were more accurate
than the classification methods in identifying agricultural areas and water
bodies. There was a higher inclusion between urban areas and bare lands due
to the similarity in their spectral reflectance. Accordingly, it is recommended
to manually digitize urban areas than classifying it. The LST can be used as
an indirect and fairly accurate method for evaluating LULC in Al-Basra city.
In conclusion, remote sensing data and techniques could help in providing
more accurate information about LULC in Basra City to be used in its future
planning and sustainable development.

\section{INTRODUCTION}

$\mathrm{N}$ OWADAYS, Basra governorate is facing a serious problem such as shortage of water resources and land degradation. These problems cause major changes in land use/ cover

Received: (8 November, 2020) - Revised: (29 December, 2020) Accepted: (30 December, 2020)

Elmwafi, Professor of surveying and geodesy in Public Works Department, Faculty of Engineering, Mansoura University, Egypt.

Zarzoura, F, Lecturer in Public Works Department, Faculty of Engineering, Mansoura University, Egypt.

Corresponding Author: Jumaah, Z., Jr., Department of Public Works, Faculty of Engineering, Mansoura University, Egypt (e-mail: zaidalebadi@gmail.com.).
(LU/LC) within the area. Therefore, there is a need for the continuous evaluation of LU/LC to be used in future planning and sustainable development of available natural resources in the area. Currently, remotely sensed (RS) data and techniques and geographical information system (GIS) are commonly used worldwide in monitoring environmental changes and evaluation in LU/LC [1]. It is at present the most fundamental elements that affect global environmental change and sustainability research is the change in LULC [2-4].

There are several techniques under the supervised classification such as minimum distance, maximum likelihood, parallelepiped, and fuzzy classification which vary in the complexity and accuracy. The process of producing thematic map from remotely sensed data is 
called image classification. In one or more spectral bands digital numbers are used to represent spectral information. This information is used for digital image classification. Individual pixels are classified using this spectral information. For classification multispectral satellite images are used. Image classification can be supervised and unsupervised [5]. Spectral indices are also used for the identification of certain LULCs such as vegetation, water bodies, soil salinity and burnt areas and built-up areas...etc. commonly used vegetation indices include the normalized difference vegetation index [6]. The soil adjusted vegetation index [7]. Many vegetation indices like DVI Difference Vegetation Index, NDVI Normalized difference, RVI Ratio VI (also simple ratio (SR)), MSR Modified simple ratio, TNDVI Transformed NDVI, RDVI Renormalized DVI, SAVI Soil Adjusted Vegetation Index, GDVI Green DVI, GNDVI Green, GRDVI Green RDVI, MSRG Modified green simple ratio, GSAVI Green SAVI, OSAVI Optimized SAVI, MSAVI2 Modified SAVI, MGSAVI Modified GSAVI, NGI Normalized green index, GWDRVI Green wide dynamic range, and etc) were used to study vegetation covers and monitor their changes [8].

Spectral indices for studying water bodies include the normalized difference water index (NDWI), the modified normalized difference water index (MNDWI) [9]. And the world view water index (WVWI) [10] are used. While the normalized difference built-up index (NDBI) is used for detecting built-up areas. Satellite imagery is an effective way to reveal the changes on land use patterns and in order to separate urban and non-urban details lots of spectral urban indices were developed by the scientists like Normalized Difference Built-Up Index (NDBI) [11]. Optical remote sensing provides a time and cost-effective way to monitor urbanization over time. However, urban areas surrounded by arid lands / barren soil tend to overestimate them due to the spectral behavior similar to both urban and surrounding areas, which leads to the difficulty of using spectral indicators like NDBI index to monitor urban expansion and resorting to semi-automatic techniques[12].

Ni Finally, Land surface temperature (LST) is also affected by the dominant LU/LC in the area, where there is an interchangeable relationship between them. Urban areas for instance are known to increase LST when compared with agricultural area. Therefore, this relationship between LU/LC and LST can be used as an indirect method for evaluating LU/LC Remote sensing uses LST technologies to create Earth and Atmospheric exchange models that help us calculate and analyze LU/LC (Therefore, this relationship between LULC and LST can be used as an indirect method for evaluating LULC Remote sensing uses LST technologies to create Earth and Atmospheric exchange models that help us calculate and analyze LULC [13-14].

In this study, both remote sensing data and techniques were used for the evaluation of LULC in Al-Basra City, Iraq. Evaluated land uses include agricultural lands, urban areas and water bodies in 2018. Studied techniques include: the supervised classification in three different methods (minimum distance, maximum likelihood, and
Mahalanobis distance), spectral indices (NDVI, SAVI, NDWI and WVWI), manual digitizing of built-up area and calculation of LST.

\section{MATERIALS AND METHODS}

\section{A. Study Area}

Basra city is the capital of Al-Basra governorate, it is about $445 \mathrm{~km}$ to the south of Baghdad, it is located in the far south of Iraq between these coordinates $47^{\circ} 30^{\prime} 0^{\prime}$ ' E and $30^{\circ} 50^{\prime} 0^{\prime \prime}$ N. It covers an area of about $1151 \mathrm{~km}^{2}$ as illustrated in Figure (1). Surface elevation of Basra varies from 5 to $26 \mathrm{~m}$ above sea level. The weather is very hot and dry in summer and cold and wet in winter. The maximum temperature ranges between $34^{\circ} \mathrm{C}$ in January and $54^{\circ} \mathrm{C}$ in July (about $31.2^{\circ} \mathrm{C}$ in average).

The minimum temperature ranges between $-6{ }^{\circ} \mathrm{C}$ in January and $21^{\circ} \mathrm{C}$ in August (about $17.6{ }^{\circ} \mathrm{C}$ in average). The mean 0annual rainfall is about $152 \mathrm{~mm}$. These weather data were downloaded from this website (https://en.climate-data.org/location/4555/).

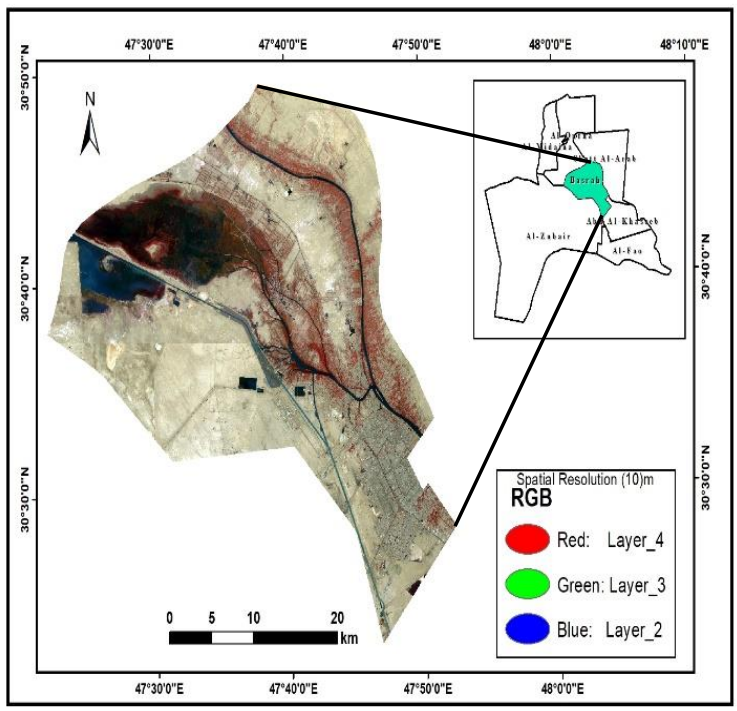

Figure (1): Location map of Basra Governorate in Iraq.

\section{B. Software and Websites Used in this Study}

The following programs and websites were used this research namely, USGS for satellite images sensor data, ESA for satellite images sensor data, Google earth for satellite images, ArcGIS desktop (ver.10.5), Erdas imagine (ver. 2015), and Microsoft excels (ver. 2016) to produce statistical analysis, perform calculation, export tables and clustered charts.

\section{Sources of Data}

Multi-temporal and multispectral Landsat data are used in this study. The date is covered by Landsat images (Path 166 rows 38) in 2018. These images were downloaded from Landsat archive available for free on United States Geological Survey (USGS) website (http://earthexplorer.usgs.gov/).

Also, two sentinel images (S2A_MSIL1C_N0206_R049_T38RQU T094703, and T094053) are used for Al-Basra district in 2018. These data were downloaded from the Sentinel archive available on European Space Agency (ESA) website 
(https://scihub.copernicus.eu/dhus/\#/home). Clouds in the downloaded images were less than $10 \%$. The characteristics of the studied remotely sensed images in 2018 are represented in Table (1).

TABLE (1)

CHARACTERISTICS OF THE STUDIED REMOTELY SENSED IMAGES IN 2018.

\begin{tabular}{|c|c|c|c|c|}
\hline Sat. Series & Landsat 8 & Landsat 8 & \multicolumn{2}{|c|}{ Sentinel } \\
\hline $\begin{array}{l}\text { Type of } \\
\text { Sensor }\end{array}$ & $\begin{array}{l}\text { (OLI- } \\
\text { TIRS) }\end{array}$ & $\begin{array}{l}\text { (OLI- } \\
\text { TIRS) }\end{array}$ & \multicolumn{2}{|c|}{ (S2A_MSIL1C) } \\
\hline $\begin{array}{c}\text { Spatial } \\
\text { Resolution }\end{array}$ & $30 \mathrm{~m}$ & $15 \mathrm{~m}$ & \multicolumn{2}{|c|}{$10 \mathrm{~m}$} \\
\hline $\begin{array}{l}\text { No. of } \\
\text { Bands }\end{array}$ & 11 & 11 & \multicolumn{2}{|c|}{12} \\
\hline Path & 166 & 166 & \multirow[t]{2}{*}{ T094703 } & \multirow[t]{2}{*}{ T094053 } \\
\hline Row & 38 & 38 & & \\
\hline Date & $28 / 09 / 2018$ & $28 / 09 / 2018$ & 19/08/2018 & $28 / 09 / 2018$ \\
\hline Sources & USGS & USGS & \multicolumn{2}{|c|}{ ESA } \\
\hline
\end{tabular}

D. Methodology and Analyses of remotely sensed data:

\section{i. Layer Stacking:}

The studied images were downloaded in a compressed zip file format. They are decompressed using file decompression software (i.e., 7 Zip). The decompressed folder contains the spectral bands in separate Geo-Tiff and JPEG2000 file formats. It also contains the metadata in a text file format. Consequently, these separated bands need to be combined and/ or stacked in one file to facilitate image preprocessing and analysis.

\section{ii. Atmospheric and Geometric Corrections:}

The studied images were atmospherically corrected to get rid of the effect of haze, dust and smoke in the images. They first are converted into at atmosphere reflectance and then into at surface reflectance using both atmospheric calibration and dark object subtraction methods in ENVI software package (ver. 5.3). Geometrically correction was carried out based on the old images acquired in 1990 using the polynomial approach. All images are projected using the Universal Transverse Mercator (UTM) projection, zone $38 \mathrm{~N}$ and WGS 1984 datum. About 20 Ground Control Points (GCPs) were randomly selected throughout each image. The Root Mean Square Error (RMS) was less than $0.5 \mathrm{~m}$ for each image.

\section{iii. Image Mosaic and Subset}

The geometrically corrected images were mosaiced together for each study period using the mosaic tool in ERDAS. These images were clipped (image subset) to cover the studied area

\section{Supervised Classification}

The trainee should have prior knowledge of the study area (Earth facts) when using supervised classification technique. which may be obtained from different groups into four classes (urban, vegetation, bare) lands and surface water extent. The ground-truth samples are introduced as sets of pixels selected to represent actual phenomena to train the computer system to recognize data patterns. The supervised classification process is carried out with a variety of techniques.

\section{a) Minimum distance supervised classification}

The minimum distance law calculates the spectral distance between the measurement vector for the candidate pixel and the mean vector for each signature. The equation for classifying by spectral distance is based on the equation for Euclidean distance, [15]:

$S D_{x y c}=\sqrt{\sum_{i=}^{n}\left(\left(\mu_{c i}-\mathrm{Xxyi}\right)^{2}\right)} \ldots \ldots$

Where:

$X_{x y i}=$ data file value of pixel $x, y$ in band $i$.

$\mathrm{i}=\mathrm{a}$ particular band.

$\mathrm{n}=$ number of bands.

$\mathrm{c}=\mathrm{a}$ particular class.

$\mu_{\mathrm{ci}}=$ mean of data file values in band $\mathrm{i}$ for the sample for class $\mathrm{c}$.

$\mathrm{SD}_{\mathrm{xyc}}=$ spectral distance from pixel $\mathrm{x}, \mathrm{y}$ to the mean of class $\mathrm{c}$.

b) Mahalanobis distance supervised classification

The mahalanobis distance is similar to the minimum distance, exclude that the covariance matrix is used in the equation. Variance and covariance are calculated in so that clusters that are highly different lead to similarly different classes, and vice versa. The equation for the Mahalanobis distance supervised classification is as follows, [15]:

Where:

$$
D=\left(X-M_{c}\right) \operatorname{Cov}_{c}-1\left(X-M_{c}\right) \quad \ldots \ldots .
$$

$\mathrm{D}=$ Mahalanobis distance.

$\mathrm{c}=\mathrm{a}$ particular class.

$\mathrm{X}=$ the measurement vector of the candidate pixel.

$\mathrm{M}_{\mathrm{c}}=$ the mean vector of the signature of class $\mathrm{c}$.

$\mathrm{Cov}_{\mathrm{c}}=$ the covariance matrix of the pixels in the signature of class c.

$\mathrm{Cov}_{\mathrm{c}}^{-1}=$ inverse of $\mathrm{Cov}_{\mathrm{c}}$.

$\mathrm{T}=$ transposition function.

\section{c) Maximum likelihood supervised classification}

The maximum likelihood law is based on the probability that a pixel belongs to a particular class.

The basic equation supposes that these probabilities are equal for all classes, and that the input bands have ordinary distributions. If a priori knowledge that the probabilities are not equal for all classes is given, then one can specify weight factors for classes. This variation of the maximum likelihood decision rule is known as the Bayesian decision rule. The equation for the maximum likelihood/Bayesian classifier is as follows, [16]:

$$
\begin{array}{r}
D=\ln a_{c}-\left[0.5 \ln \left(\left|\operatorname{Cov}_{c}\right|\right)\right]-\left[\left(0 . 5 \left(X-M_{c)}{ }^{T}\left(\operatorname{Cov}_{c}{ }^{-1}\right)\right.\right.\right. \\
\left.\left.\left(X-M_{c}\right)\right)\right] \ldots \ldots(3)
\end{array}
$$

Where:

$\mathrm{D}=$ weighted distance (likelihood).

$\mathrm{C}=$ a particular class.

$\mathrm{X}=$ the measurement vector of the candidate pixel.

$\mathrm{M}_{\mathrm{c}}=$ the mean vector of the sample of class $\mathrm{c}$. 
$\mathrm{A}_{\mathrm{c}}=$ the percent probability that any candidate pixel is a member of class $c$

(defaults to 1.0 , or is entered from a priori knowledge).

Covc $=$ the covariance matrix of the pixels in the sample of class c.

$|\operatorname{Covc}|=$ the determinant of Covc (matrix algebra).

$\mathrm{Cov}_{\mathrm{c}}{ }^{-1}=$ inverse of Covc (matrix algebra).

$\ln =$ natural logarithm function.

$\mathrm{T}=$ transposition function (matrix algebra).

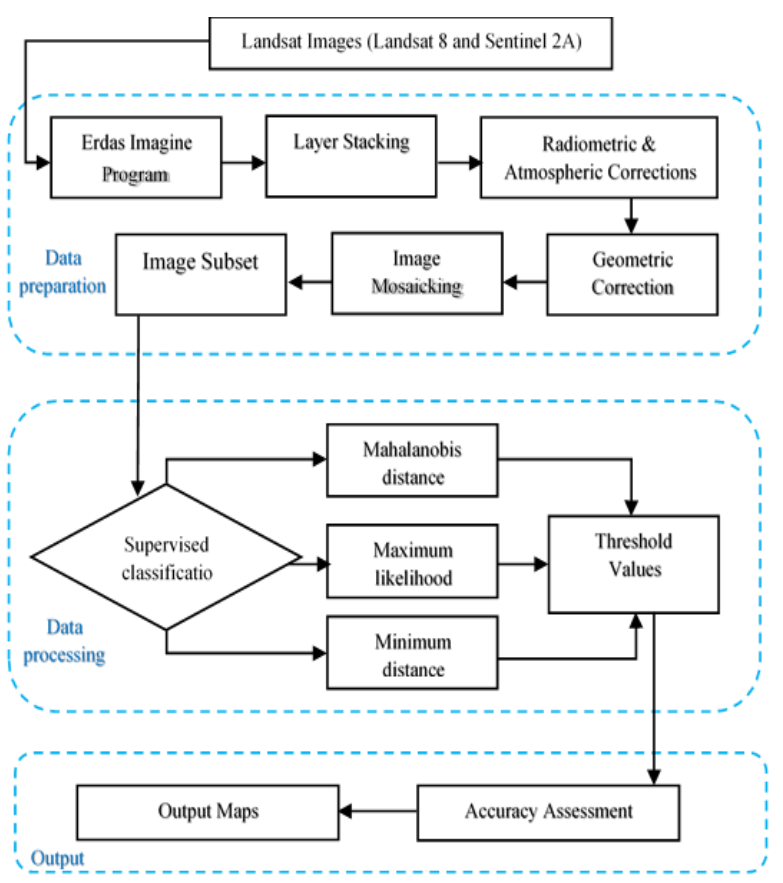

Fig. (2): Flow chart of data analysis by supervised classification.

\section{Classifications by Land surface temperature}

Some satellites carry thermal sensors. For example, Landsat TM/ETM, NOAA AVHRR ASTER, MODIS, etc. Thermal band records thermal emissive from the land surface objects. This band is good for studying surface temperature (Ts) at different land use/covers. For example, some researchers use surface temperature an NDVI to classify the land use land cover. Thermal band spatial resolution is normally coarser than other bands because temperature does not change much within smaller areas. Land surface temperature is calculated in the following steps:

\section{a. Conversion to TOA Radiance}

OLI and TIRS band data can be converted to TOA spectral radiance using the radince rescaling factors provided in metadata file [17]:

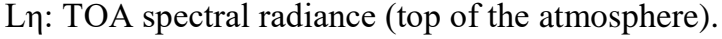

$$
\mathrm{L}_{\eta}=\mathrm{M}_{\mathrm{L}} \mathrm{Q}_{\mathrm{cal}}+\mathrm{A}_{\mathrm{L}} \ldots \ldots
$$

Where:

$\mathrm{L}_{\eta} \quad$ TOA spectral radiance (top of the atmosphere).

$\mathrm{M}_{\mathrm{L}}$ multiplicative rescaling factor from metadata.

where $\mathrm{x}$ is the band number.

$\mathrm{Q}_{\text {cal }} \quad$ Quantized and calibrated standard product pixel values.
$\mathrm{A}_{\mathrm{L}}$ Band-specific additive rescaling factor from metadata.

\section{b. Conversion to Top of Atmosphere Brightness Temperature}

Tirs band data can be coverted from spactral radiance to Top of Atmosphere Brightness Temperature using the thermal constant that provided in the metadata file [17]:

$$
T B=\frac{K 2}{\ln \left(\frac{K 1}{\mathrm{~L} \eta}+1\right)} *-273.15 \ldots \ldots
$$

Where:

TB Atmosphere brightness temperature (K), where -273.15 to convert to $\left({ }^{\circ} \mathrm{C}\right)$.

K1 Band-specific thermal conversion constant from metadata.

K2 Band-specific thermal conversion constant from metadata.

$\mathrm{L}_{\eta}$ TOA spectral radiance (top of the atmosphere).

\section{c. Conversion from At-Satallite Temperature to Land Suface Temperature}

To convert the at-satallite temperature to land suface temperature we use this equation [17]:

$$
T=\frac{T B}{\left[1+\left(\frac{\Lambda * T B}{c 2}\right) * \ln (e)\right]} \ldots \ldots .
$$

Where:

$\Lambda \quad$ Wave length of emitted radiance $10.8 \mu \mathrm{m}$ for landsat 8 .

C2 constant $14388 \mu \mathrm{m} \mathrm{k}$.

TB Atmosphere brightness temperature.

$$
\mathrm{PV}=\left(\left(\mathrm{NDVI}_{-} \mathrm{NDVI}_{\min }\right) /\left(\mathrm{NDVI}_{\max }-\mathrm{NDVI}_{\min }\right)\right)^{2}
$$$$
\mathrm{e}=0.004 \mathrm{pv}+0.986
$$

\section{Classifications by spectral indices}

As shown in Table (2) Two vegetation indices were used in this work to evaluate the vegetation cover within the studied area. These indices are the Normalized Difference Vegetation Index (NDVI) and the Soil Adjusted Vegetation Index (SAVI). Also, two water indices were also used in this work to study monitor and evaluate the spatial extent of water bodies in their changes in the studied area. These indices include the Normalized Difference Water Index (NDWI) and the World View Water Index (WVWI) as described below.

\section{Table (2)}

Summary of the Spectral Indices used to in this work.

\begin{tabular}{c||l||l||l||l}
\multicolumn{2}{c||}{ Indices } & Symbol & \multicolumn{1}{|c||}{ Equation* } & Reference \\
\hline 1 & $\begin{array}{l}\text { World view } \\
\text { water index }\end{array}$ & WVWI & (B-NIR) / (B+NIR) & $\begin{array}{l}\text { (Wolf, A. } \\
\text { F. 2012) }\end{array}$ \\
\hline 2 & $\begin{array}{l}\text { Normalize } \\
\text { difference } \\
\text { water index }\end{array}$ & NDWI & (G-NIR) / (G+NIR) & $\begin{array}{l}\text { (McFeeters } \\
\text { in 1996) }\end{array}$ \\
\hline 3 & $\begin{array}{l}\text { Soil } \\
\text { adjustive } \\
\text { vegetation } \\
\text { index }\end{array}$ & SAVI & (NIR - R) $\times(1+\mathrm{L}) /$ & $\begin{array}{l}\text { (Huete, } \\
1988)\end{array}$ \\
\hline 4 & $\begin{array}{l}\text { Normalize } \\
\text { difference } \\
\text { vegetation } \\
\text { index }\end{array}$ & NDVI & (NIR- R) / (NIR+ R) & $\begin{array}{l}\text { Rouse et } \\
\text { al., 1973) }\end{array}$ \\
\hline
\end{tabular}

Where: B, G, R and NIR correspond to the blue (band 2), green (band 3 ), red (band 4) and near infrared (band 5) bands in Landsat 8 imagery, respectively. Overwise, B, G, R and NIR correspond to the 
blue (band 1), green (band 2), red (band 3 ) and near infrared (band 4) bands in Landsat (4, 5 and 7) imagery, respectively. Also, B, G, R and NIR correspond to the blue (band 2), green (band 3), red (band 4) and near infrared (band 8) bands in Sentinel 2A imagery, respectively.

\section{Accuracy Assessment}

Accuracy Assessment was performed on the produced binary images from all the studied indices (NDVI, SAVI, NDWI and WVWI) in 2018. This was to evaluate the accuracy of each index in classifying agricultural against non-agricultural areas and water bodies against dry lands. The classified image was matched with a variety of data such as aerial photographs, high resolution satellite image and ground data. Four types of accuracy were calculated for each classified image as described by Campbell and Wynne (2011) [18]. They are:1) User's accuracy, 2) Producer's accuracy, 3) Overall accuracy, and 4) Kappa coefficient.

The following is an example on how these four types of accuracies are calculated. Table (3) shows the number of correctly classified records in each category (Good records) and the number of incorrectly classified records in that category (Bad records).

\section{Table (3)}

The number of correctly (Good records) and incorrectly (Bad records)

\begin{tabular}{|c|c|c|c|}
\hline Records & Good Records & Bad Records & Total \\
\hline $\begin{array}{c}\text { Good } \\
\text { Records }\end{array}$ & Good Records & Bad Records & TR \\
\hline $\begin{array}{c}\text { Bad } \\
\text { Records }\end{array}$ & Bad Records & Good Records & TR \\
\hline Total & TC & TC & TD \\
\hline
\end{tabular}

1) Calculation of user's accuracy $(U A)$ :

Where:

$$
U A=\frac{C R}{T R} \ldots \ldots
$$

UA: User accuracy.

CR: The number of correctly classified records in each row category.

TR: The total number of classified records in the same row category.

2) Calculation of user's accuracy (PA):

$$
P A=\frac{C C}{T C} \ldots \ldots
$$

Where:

PA: Producer accuracy.

$\mathrm{CC}$ : The number of correctly classified records in each column category.

TC: The total number of classified records in the same column category.

3) Calculation of overall accuracy (OA):

$$
O A=\frac{C D}{T P} \ldots
$$

Where:

OA: Overall accuracy.

CD: The number of correctly classified pixels in diagonal.
TP: The total number of referenced records.

4) Calculation of user's accuracy $(\mathrm{KC})$ :

Where:

$$
K C=\frac{(T P * C D)-\sum(T C * T R)}{T P^{2}-\sum(T C * T R)} \ldots \ldots
$$

KC: Kappa coefficient.

\section{RESUlTS AND DISCUSSIONS}

\section{A. Supervised Classification}

The supervised classification was used to identify land use/cover and their areas in Al-Basra city center in 2018. Three methods of classification were used in this work. They are: 1) minimum distance, 2) maximum likelihood, and 3) Mahalanobis distance. These methods were applied on both Sentinel 2A and Landsat data at three spatial resolutions 10,15 and $30 \mathrm{~m}$, respectively. The following are the results of LULC obtained for each spatial resolution:

\section{Land use/ cover Classifications from Sentinel $2 A$ (10 m) data:}

Table 4 shows the results of LULC classification by the three mention methods on Sentinel 2A data for 2018. There were wide differences in the areas of each LULC between these methods. The minimum distance method indicated that the areas of bare land, urban land, vegetation land, and water land were about 551.13, $336.68,100.90$ and $162.12 \mathrm{~km}^{2}$, respectively. The maximum likelihood method showed that the areas of bare land, urban land, vegetation land, and water land were 459.57, 402.57, 156.89, and $131.80 \mathrm{~km}^{2}$, respectively. The Mahalanobis distance method provided that the areas of bare land, urban land, vegetation land, and water land were about 449.41, 411.01, 159.96, and $130.45 \mathrm{~km}^{2}$, respectively.

\begin{tabular}{|c|c|c|c|c|c|c|}
\hline \multirow{2}{*}{$\begin{array}{l}\text { Land } \\
\text { use/ } \\
\text { cover }\end{array}$} & \multicolumn{2}{|c|}{ Minimum distance } & \multicolumn{2}{|c|}{$\begin{array}{l}\text { Maximum } \\
\text { likelihood }\end{array}$} & \multicolumn{2}{|c|}{$\begin{array}{l}\text { Mahalanobis } \\
\text { Distance }\end{array}$} \\
\hline & $\begin{array}{l}\text { Area } \\
\mathrm{km}^{2}\end{array}$ & $\%$ & $\begin{array}{l}\text { Area } \\
\mathrm{km}^{2}\end{array}$ & $\%$ & $\begin{array}{l}\text { Area } \\
\mathrm{km}^{2}\end{array}$ & $\%$ \\
\hline $\begin{array}{l}\text { Bare } \\
\text { Land }\end{array}$ & 551.13 & 47.89 & 459.57 & 39.93 & 449.41 & 39.05 \\
\hline $\begin{array}{l}\text { Urban } \\
\text { Land }\end{array}$ & 336.68 & 29.26 & 402.57 & 34.98 & 411.01 & 35.71 \\
\hline $\begin{array}{l}\text { Veg. } \\
\text { Land }\end{array}$ & 100.90 & 8.77 & 156.89 & 13.63 & 159.96 & 13.90 \\
\hline $\begin{array}{l}\text { Water } \\
\text { Land }\end{array}$ & 162.12 & 14.09 & 131.80 & 11.45 & 130.45 & 11.34 \\
\hline Total & 1150.83 & 100 & 1150.83 & 100 & 1150.83 & 100.00 \\
\hline
\end{tabular}

Table (4)

supervised classification with Sentinel 2A satellite $(10 \mathrm{~m})$ for Al-Basra city.

Accuracy assessment was carried out on each LULC obtained from each classification method as represented in Table 5. It was observed that the LULC obtained by using the minimum distance classification method was higher in accuracy when compared with the two other methods. These results reveal that both agricultural land and water areas were classified with higher accuracies, whereas urban areas and bare land were classified at lower accuracies. These lower accuracies in identifying 
both urban areas and bare land could be attributed to the similarity between them in their spectral reflectance.

Table (5)

Accuracy Assessment of Land use/ cover obtained by the three studied classification methods on Sentinel 2A data.

\begin{tabular}{|c|c|c|c|c|c|}
\hline $\begin{array}{l}\text { Classification } \\
\text { Method }\end{array}$ & $\begin{array}{l}\text { Type of } \\
\text { Accuracy }\end{array}$ & Water & $\begin{array}{l}\text { Urban/ } \\
\text { Built up }\end{array}$ & Agric. & $\begin{array}{l}\text { Bare } \\
\text { Land }\end{array}$ \\
\hline \multirow{4}{*}{$\begin{array}{l}\text { Maximum } \\
\text { Likelihood }\end{array}$} & UA & 72.73 & 72.97 & 66.67 & 73.81 \\
\hline & PA & 72.73 & 100.00 & 76.92 & 91.18 \\
\hline & OA & \multicolumn{4}{|c|}{80.00} \\
\hline & Kappa & \multicolumn{4}{|c|}{0.71} \\
\hline \multirow{4}{*}{$\begin{array}{c}\text { Minimum } \\
\text { Distance }\end{array}$} & UA & 94.74 & 75.49 & 85.71 & 70.00 \\
\hline & $\mathrm{PA}$ & 100.00 & 100.00 & 100.00 & 98.36 \\
\hline & $\overline{\mathrm{OA}}$ & \multicolumn{4}{|c|}{86.61} \\
\hline & Kappa & \multicolumn{4}{|c|}{0.79} \\
\hline \multirow{4}{*}{$\begin{array}{c}\text { Mahalanobis } \\
\text { Distance }\end{array}$} & UA & 72.22 & 58.97 & 61.54 & 73.17 \\
\hline & $\mathrm{PA}$ & 81.25 & 100.00 & 71.54 & 85.71 \\
\hline & OA & \multicolumn{4}{|c|}{80.00} \\
\hline & Kappa & \multicolumn{4}{|c|}{0.71} \\
\hline
\end{tabular}

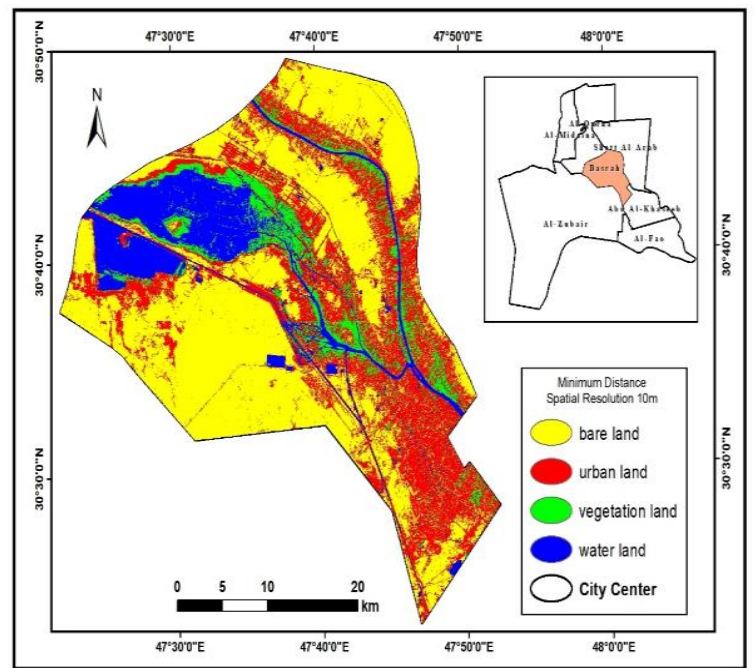

Figure (3): Land use/ cover by using the minimum distance technique.

\section{B. Land use/ cover from Landsat $8(15 \mathrm{~m})$ data}

Table 6 shows the results of LULC classification by the three mention methods on Sentinel 2A data for 2018. There were wide differences in the areas of each LULC between these methods. The minimum distance method indicated that the areas of bare land, urban land, vegetation land, and water land were about 452.70, 384.48, 139.44, and $174.50 \mathrm{~km}^{2}$, respectively. The maximum likelihood method showed that the areas of bare land, urban land, vegetation land, and water land were 352.81, 510.37, 185.67, and $102.27 \mathrm{~km}^{2}$, respectively. The Mahalanobis distance method provided that the areas of bare land, urban land, vegetation land, and water land were about 315.65, 550.74, 183.76, and $100.97 \mathrm{~km}^{2}$, respectively.
Table (6)

Land use/ cover in Al-Basra city using three methods of supervised classification on Landsat 8 (15 m).

\begin{tabular}{|c|c|c|c|c|c|c|}
\hline \multirow{2}{*}{$\begin{array}{c}\begin{array}{c}\text { Classification } \\
\text { method }\end{array} \\
\begin{array}{c}\text { Land use/ } \\
\text { cover }\end{array}\end{array}$} & \multicolumn{2}{|c|}{$\begin{array}{l}\text { Minimum } \\
\text { distance }\end{array}$} & \multicolumn{2}{|c|}{$\begin{array}{l}\text { Maximum } \\
\text { likelihood }\end{array}$} & \multicolumn{2}{|c|}{$\begin{array}{l}\text { Mahalanobis } \\
\text { Distance }\end{array}$} \\
\hline & $\begin{array}{l}\text { Area } \\
\left(\mathrm{km}^{2}\right)\end{array}$ & $\%$ & $\begin{array}{l}\text { Area } \\
\left(\mathrm{km}^{2}\right)\end{array}$ & $\%$ & $\begin{array}{l}\text { Area } \\
\left(\mathrm{km}^{2}\right)\end{array}$ & $\%$ \\
\hline Bare Land & 452.70 & 39.33 & 352.81 & 30.65 & 315.65 & 27.42 \\
\hline Urban Land & 384.48 & 33.40 & 510.37 & 44.34 & 550.74 & 47.84 \\
\hline Veg. Land & 139.44 & 12.11 & 185.67 & 16.13 & 183.76 & 15.96 \\
\hline Water Land & 174.50 & 15.16 & 102.27 & 8.88 & 100.97 & 8.77 \\
\hline Total & 1151.13 & 100 & 1151.13 & 100 & 1151.13 & 100 \\
\hline
\end{tabular}

Accuracy assessment was carried out on each LULC obtained from each classification method as represented in Table 7. It was observed that the LULC obtained by using the minimum distance classification method was higher in accuracy when compared with the two other methods. These results reveal that both agricultural land and water areas were classified with higher accuracies, whereas urban areas and bare land were classified at lower accuracies. These lower accuracies in identifying both urban areas and bare land could be attributed to the similarity between them in their spectral reflectance.

Table (7)

Accuracy Assessment of Land use/ cover obtained by the three studied classification methods on Landsat 8 data.

\begin{tabular}{|c|c|c|c|c|c|}
\hline $\begin{array}{c}\text { Classification } \\
\text { Method }\end{array}$ & $\begin{array}{l}\text { Type of } \\
\text { Accuracy }\end{array}$ & Water & $\begin{array}{l}\text { Urban/ } \\
\text { Built up }\end{array}$ & Agriculture & $\begin{array}{l}\text { Bare } \\
\text { Land }\end{array}$ \\
\hline \multirow{4}{*}{$\begin{array}{l}\text { Maximum } \\
\text { Likelihood }\end{array}$} & User's & 60.00 & 69.70 & 70.00 & 64.29 \\
\hline & Producer's & 66.67 & 100.00 & 75.00 & 81.82 \\
\hline & Overall & \multicolumn{4}{|l|}{78.49} \\
\hline & Kappa & \multicolumn{4}{|l|}{0.69} \\
\hline \multirow{4}{*}{$\begin{array}{c}\text { Minimum } \\
\text { Distance }\end{array}$} & User's & 76.19 & 70.15 & 80.49 & 69.55 \\
\hline & Producer's & 84.21 & 100.00 & 87.78 & 89.19 \\
\hline & Overall & \multicolumn{4}{|l|}{79.31} \\
\hline & Kappa & \multicolumn{4}{|l|}{0.70} \\
\hline \multirow{4}{*}{$\begin{array}{l}\text { Mahalanobis } \\
\text { Distance }\end{array}$} & User's & 66.67 & 66.67 & 60.00 & 66.67 \\
\hline & Producer's & 80 & 95.83 & 75.00 & 84.62 \\
\hline & Overall & \multicolumn{4}{|l|}{76.40} \\
\hline & Kappa & \multicolumn{4}{|l|}{0.67} \\
\hline
\end{tabular}

Also. It was observed that the LULC obtained by using the minimum distance classification method was higher in accuracy when compared with the two other methods for pan sharpening Landsat $8(15 \mathrm{~m})$. 


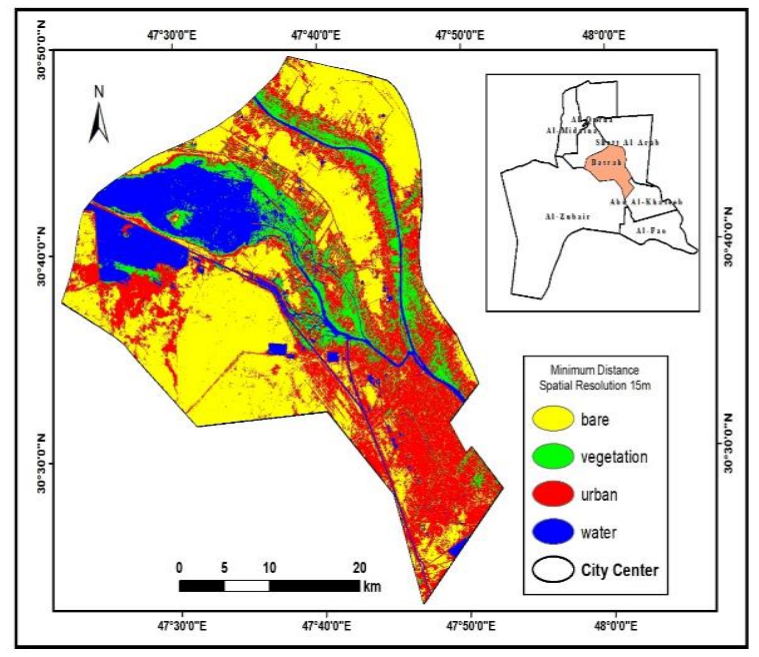

Figure (4): Land use/ cover by using the minimum distance technique.

\section{Land use/ cover from Landsat $8(30 \mathrm{~m})$ data}

Table 8 shows the results of LULC classification by the three mention methods on Sentinel 2A data for 2018. There were wide differences in the areas of each LULC between these methods. The minimum distance method indicated that the areas of bare land, urban land, vegetation land, and water land were about 363.46, 468.90, 149.21, and $170.80 \mathrm{~km}^{2}$, respectively. The maximum likelihood method showed that the areas of bare land, urban land, vegetation land, and water land were 352.79, 500.79, 193.81, and $104.97 \mathrm{~km}^{2}$, respectively. The Mahalanobis distance method provided that the areas of bare land, urban land, vegetation land, and water land were about 323.20, 539.87, 186.31, and $102.98 \mathrm{~km}^{2}$, respectively. Figure 5 illustrate the LULC classification images obtained from the minimum distance technique.

Table (8)

Land use/ cover in Al-Basra city using three methods of supervised classification on Landsat $8(30 \mathrm{~m})$

\begin{tabular}{|c|c|c|c|c|c|c|}
\hline $\begin{array}{c}\text { Classification } \\
\text { method }\end{array}$ & $\begin{array}{r}\text { Mini } \\
\text { dista }\end{array}$ & & $\begin{array}{l}\text { Maxi } \\
\text { likeli }\end{array}$ & & $\begin{array}{r}\text { Maha } \\
\text { Dis }\end{array}$ & \\
\hline $\begin{array}{c}\text { Land use/ } \\
\text { cover }\end{array}$ & $\begin{array}{r}\text { Area } \\
\left(\mathrm{km}^{2}\right)\end{array}$ & $\%$ & & $\%$ & $\begin{array}{r}\text { Area } \\
\left(\mathrm{km}^{2}\right)\end{array}$ & $\%$ \\
\hline Bare Land & 363.46 & 01.04 & 352.79 & $P 0.01$ & 32320 & 28.05 \\
\hline$\overline{\text { Urbar }}$ & 468.90 & 40.69 & 500.79 & 43.46 & 539.87 & 46.85 \\
\hline Veg. Land & 140 & 1295 & 103 & 16.82 & 186. & 16.17 \\
\hline Water Land & 170.80 & 14.82 & 104.97 & 9.11 & 102.98 & 8.94 \\
\hline 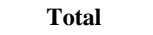 & 52.37 & 100 & 152.37 & 100 & 1152.37 & 100 \\
\hline
\end{tabular}

Accuracy assessment was carried out on each LULC obtained from each classification method as represented in Table 9. It was observed that the LULC obtained by using the minimum distance classification method was higher in accuracy when compared with the two other methods. These results reveal that both agricultural land and water areas were classified with higher accuracies, whereas urban areas and bare land were classified at lower accuracies. These lower accuracies in identifying both urban areas and bare land could be attributed to the similarity between them in their spectral reflectance.
Table (9):

Accuracy Assessment of Land use/ cover obtained by the three studied classification methods on Landsat 8 data.

\begin{tabular}{|c|c|c|c|c|c|}
\hline $\begin{array}{r}\text { Classification } \\
\text { Method }\end{array}$ & $\begin{array}{r}\text { Type of } \\
\text { Accuracy }\end{array}$ & Water & $\begin{array}{l}\text { Urban/ } \\
\text { Built up }\end{array}$ & Agriculture & Bare Land \\
\hline \multirow{4}{*}{$\begin{array}{r}\text { Maximum } \\
\text { Likelihood }\end{array}$} & User's & 86.67 & 63.83 & 67.78 & 66.67 \\
\hline & Producer's & 96.30 & 66.75 & 78.79 & 91.18 \\
\hline & Overall & \multicolumn{4}{|c|}{72.00} \\
\hline & Kappa & \multicolumn{4}{|c|}{0.61} \\
\hline \multirow{4}{*}{$\begin{array}{r}\text { Minimum } \\
\text { Distance }\end{array}$} & User's & 74.71 & 68.67 & 80.00 & 69.19 \\
\hline & Producer's & 78.57 & 100.00 & 83.64 & 94.12 \\
\hline & Overall & \multicolumn{4}{|c|}{78.65} \\
\hline & Kappa & \multicolumn{4}{|c|}{0.69} \\
\hline \multirow{4}{*}{$\begin{array}{r}\text { Mahalanobis } \\
\text { Distance }\end{array}$} & User's & 54.55 & 52.63 & 71.43 & 54.55 \\
\hline & Producer's & 75.00 & 100.00 & 76.92 & 81.82 \\
\hline & Overall & \multicolumn{4}{|c|}{73.63} \\
\hline & Kappa & \multicolumn{4}{|c|}{0.61} \\
\hline
\end{tabular}

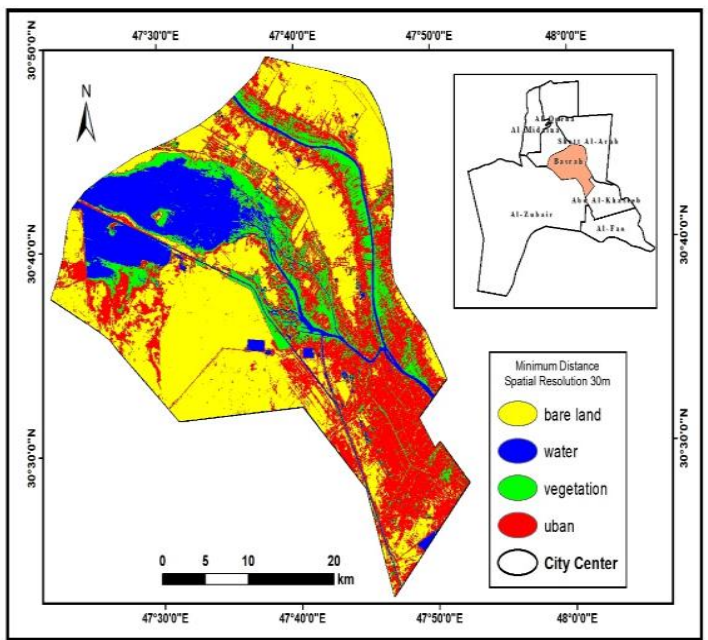

Figure (5): Land use/ cover by using the minimum distance technique.

3. Comparative study of Minimum distance classification for different spatial resolution.

As shows in figure 6 . The results of LULC classification by minimum distance method on three spatial resolutions 10,15 and $30 \mathrm{~m}$, in 2018 . There were wide differences in the areas of each LULC between these images. There is a problem in differentiating urban lands and barren land and other categories (vegetation areas, and waterbodies) as both have similar response at some places leading to over-estimation of urban lands at the expense of the barren land. Whenever, the higher spatial resolution of the image, the less interfere between its constituent categories.

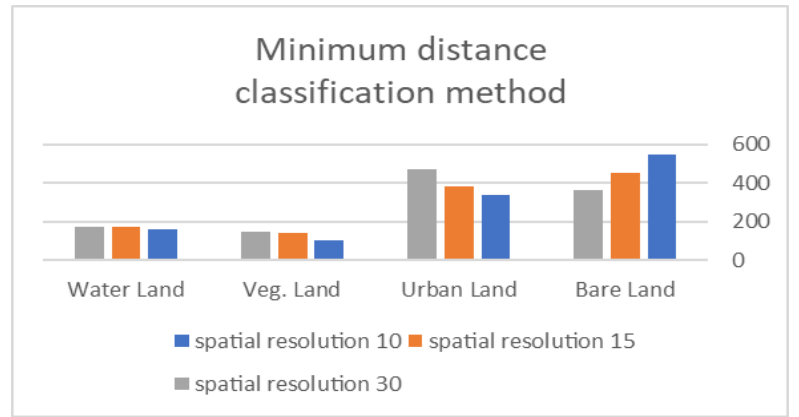

Figure (6): Comparative study of Minimum distance classification for different spatial resolution 


\section{Land use/ cover from surface temperature}

Land surface temperature in 2018 were fundamentally compose to four classes of total area which are (bare land, urban, agricultural, and water), and that the areas were
(487.94, 367.47, 113.48, and 181.76) $\mathrm{km}^{2}$, respectively. As shown In Table (10) and Fig. (7).

Table (10)

Surface temperature and their Land use/ cover.

\begin{tabular}{|c|c|c|c|c|c|c|c|}
\hline $\begin{array}{c}\text { Land use/ } \\
\text { cover }\end{array}$ & $\begin{array}{l}\text { No. of } \\
\text { point }\end{array}$ & $\begin{array}{c}\text { Min. } \\
\text { Temp. }{ }^{\circ} \mathrm{C}\end{array}$ & $\begin{array}{c}\text { Max. } \\
\text { Temp. }{ }^{\circ} \mathrm{C}\end{array}$ & $\begin{array}{c}\text { Average } \\
\text { Temp. }{ }^{\circ} \mathrm{C}\end{array}$ & STD. & $\begin{array}{l}\text { Area } \\
\left(\mathbf{k m}^{2}\right)\end{array}$ & $\%$ \\
\hline Water bodies & 74 & 26.48 & 33.14 & 29.09 & 1.85 & 181.76 & 15.80 \\
\hline Agric. Land & 39 & 33.26 & 39.96 & 36.83 & 2.10 & 113.48 & 9.86 \\
\hline Urban area & 121 & 40.00 & 44.00 & 42.35 & 1.11 & 367.47 & 31.94 \\
\hline Bare Land & 166 & 44.03 & 47.59 & 45.43 & 0.91 & 487.94 & 42.41 \\
\hline Total & & & & & & 1150.7 & 100 \\
\hline
\end{tabular}
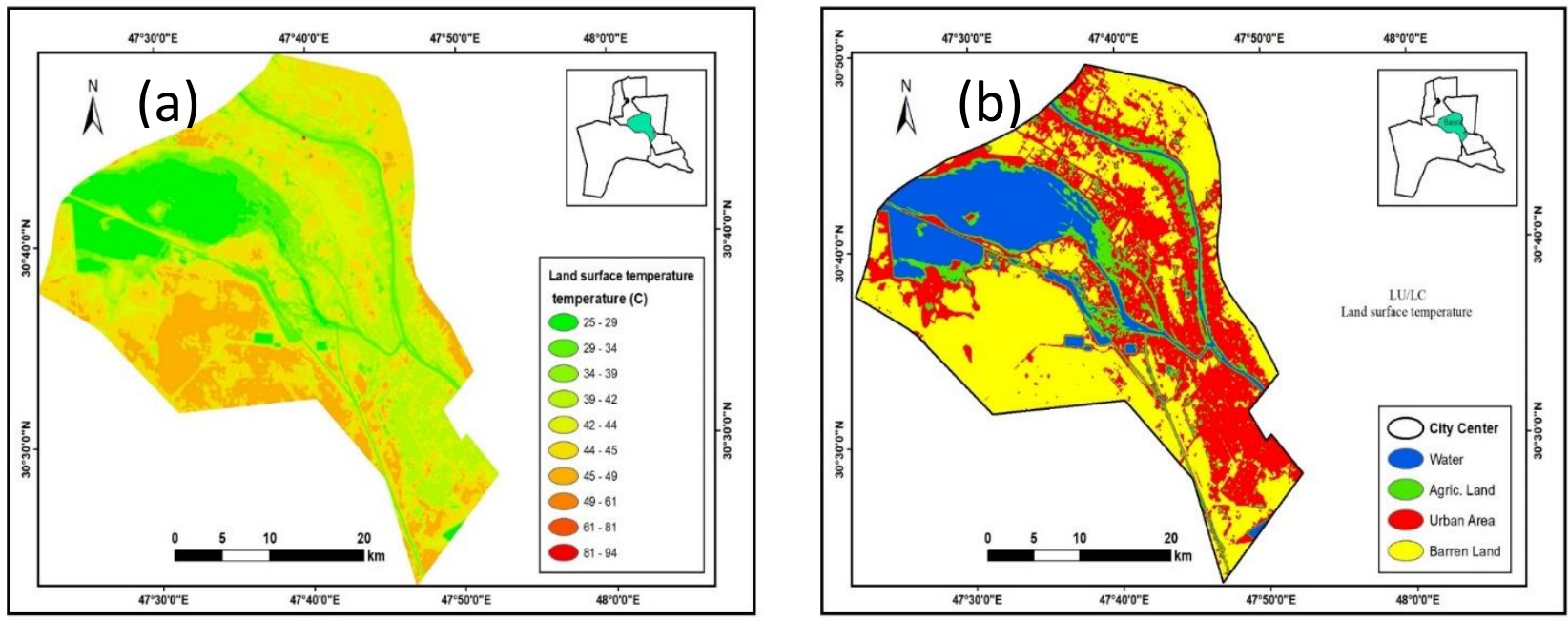

Figure (7): Spatial distribution of surface temperature and their LU/LC in Basra city: surface temperature image and b) LU/LC image.

\section{Land use/ cover from spectral indices}

\section{Agricultural lands in Basra City:}

The two studied vegetation indices (NDVI and SAVI) were carried out on the Landsat 8 and Sentinel 2A data for the city center in 2018. The obtained images were divided into two classes, which a rea the agricultural and non-agricultural areas based on the used threshold value for each image. The areas and percentages of these two classes area represented in Table 11. Also, the spatial distribution of agricultural areas derived from the NDVI and the SAVI indices is illustrated in Figures 8 and 9, respectively.

The NDVI results indicated that agricultural areas were about $134.07 \mathrm{~km}^{2}(11.66 \%)$ and $134.11 \mathrm{~km}^{2}$ $(11.66 \%)$ based on Landsat 8 and Sentinel 2A data, respectively. These results reveal that there is no significant difference between using Landsat 8 or Sentinel data in evaluating agricultural areas in Basra city center.

Otherwise, the SAVI results revealed that agricultural versus non-agricultural areas were about $170.08 \mathrm{~km}^{2}$ $(14.79 \%)$ and $168.22 \mathrm{~km}^{2}(14.63 \%)$ based on Landsat 8 and Sentinel 2A data, respectively. These results also reveal no significant difference between using Landsat 8 or Sentinel data in evaluating agricultural areas in Basra city.
Table (11)

Estimated agricultural and non-agricultural areas in Basra city center using Landsat 8 and Sentinel 2A images in 2018.

\begin{tabular}{|c|c|c|c|c|c|}
\hline \multirow{2}{*}{$\begin{array}{c}\text { Type of } \\
\text { Index }\end{array}$} & \multirow{2}{*}{$\begin{array}{c}\text { Land } \\
\text { Use/Cover }\end{array}$} & \multicolumn{2}{|c|}{ Landsat 8} & \multicolumn{2}{|c|}{ Sentinel 2A } \\
\hline & & $\begin{array}{l}\text { Area } \\
\left(\mathbf{k m}^{2}\right)\end{array}$ & $\%$ & $\begin{array}{l}\text { Area } \\
\left(\mathbf{k m}^{2}\right)\end{array}$ & $\%$ \\
\hline \multirow{3}{*}{ NDVI } & Agric. & 134.07 & 11.66 & 134.11 & 11.66 \\
\hline & Non-Agric. & 1016.1 & 88.34 & 1016.06 & 88.34 \\
\hline & Total & 1150.17 & 100 & 1150.17 & 100 \\
\hline \multirow{3}{*}{ SAVI } & Agric. Areas & 170.08 & 14.79 & 168.22 & 14.63 \\
\hline & $\begin{array}{c}\text { Non-Agric. } \\
\text { Areas }\end{array}$ & 980.09 & 85.21 & 981.96 & 85.37 \\
\hline & Total & 1150.17 & 100 & 1150.17 & 100 \\
\hline
\end{tabular}

Accuracy assessment was also carried out on the agricultural and non-agricultural area derived from the NDVI and SAVI indices on both Landsat and Sentinel 2A data as represented in Table 12.

It was observed that agricultural areas derived from Sentinel data were higher in accuracy when compared with these derived from Landsat data. However, the difference in values wasn't that significant. This could be attributed to the higher spatial resolution of Sentinel 2A data $(10 \mathrm{~m})$ when compared with the spatial resolution of Landsat 8 data $(30 \mathrm{~m})$.

It was also found that agricultural areas extracted by 
using the SAVI index was more accurate than these obtained from using the NDVI index. This could be because the SAVI takes into account the background reflectance of bare land especially under low vegetation cover.

Table (12)

Accuracy assessment parameters for agricultural areas derived from both NDVI and SAVI indices on Sentinel and Landsat data.

\begin{tabular}{|c|c|c|c|c|c|c|c|c|}
\hline \multirow{2}{*}{$\begin{array}{l}\mathrm{LU} / \mathrm{LC} \\
\text { classes }\end{array}$} & \multicolumn{4}{|c|}{ Sentinel 2A } & \multicolumn{4}{|c|}{ Landsat 8} \\
\hline & UA & & $\mathrm{OA}$ & $\mathrm{C}$ & UA & PA & $\mathrm{OA}$ & $\mathrm{KC}$ \\
\hline SAVI & 84. & & 88.11 & 0.8 & 81.29 & 84.00 & 88.06 & 0.81 \\
\hline & 81. & 87. & 87.67 & 0.8 & 80.00 & 81.00 & 87.57 & 0.19 \\
\hline
\end{tabular}
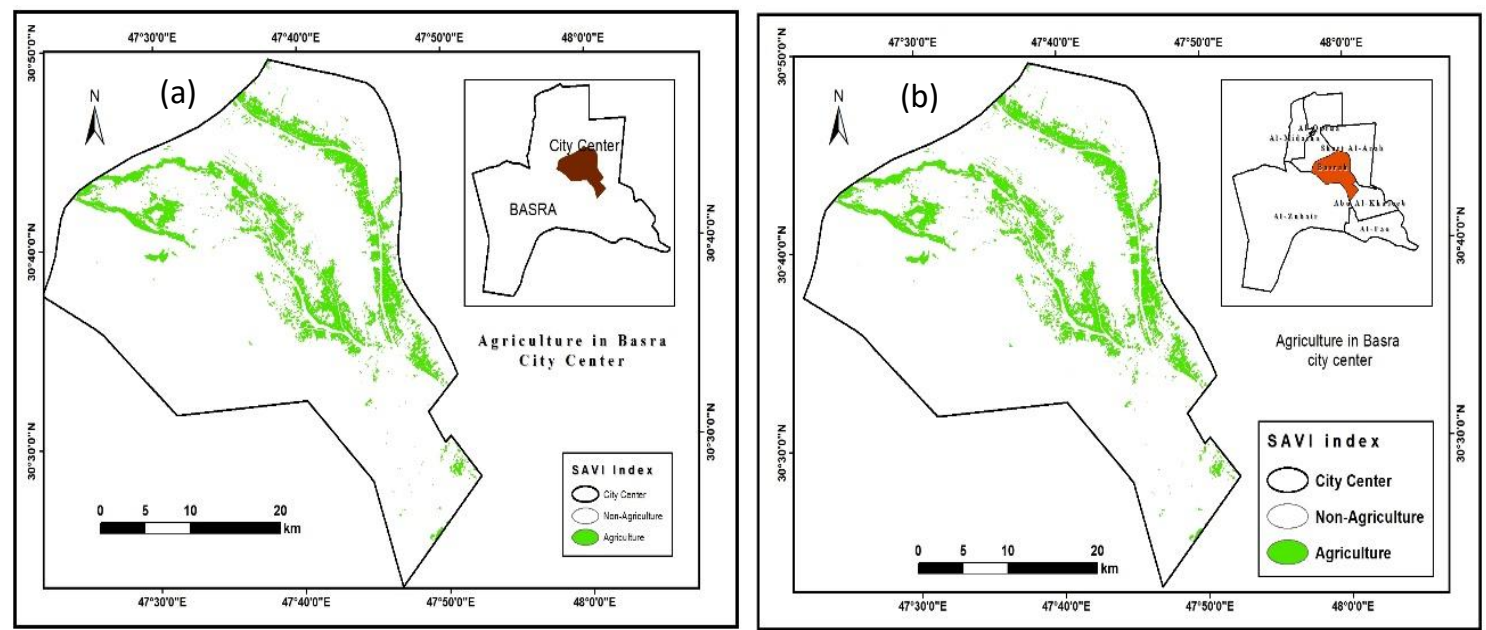

Figure (8): Spatial distribution of agricultural lands in Basra city center using the NDVI index a) Landsat 8 and b) Sentinel 2A images.
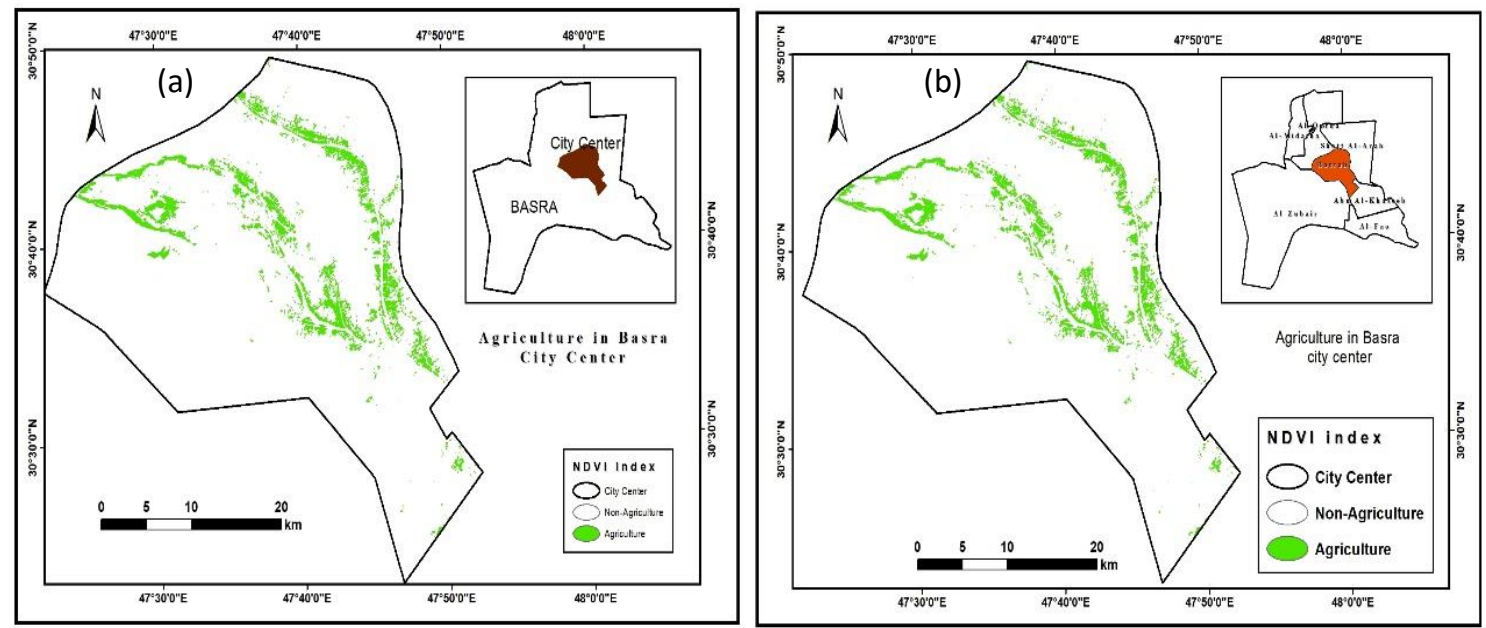

Figure (9): Spatial distribution of agricultural lands in Basra city center using the SAVI index a) Landsat 8 and b) Sentinel 2A images.

\section{Water features in Basra City:}

Water features in the studied area were studied using both the WVWI and NDWI indices on Landsat 8 and Sentinel 2A data of 2018. The derived images were also converted into binary images with two classes (water versus non-water areas). Water areas and their percentages are shown in Table 13. and illustrated in Figures $(10,11)$.

These results indicated that water areas were about $84.52 \mathrm{~km} 2(7.35 \%)$ and $82.55 \mathrm{~km} 2(7.18 \%)$ based on Landsat 8 and Sentinel 2A data, respectively. These results reveal that there is no significant difference between using Landsat 8 or Sentinel data in evaluating water areas in Basra city. There were wide variations in the water areas between the two indices and the two types of remotely sensed data. Water areas derived from Sentinel data were smaller than those derived from Landsat data. This also could be attributed to the difference between them in the resolution.

Also, water areas extracted by the WVWI were far smaller than those extracted from the NDWI index. This could also be attributed to the types of spectral bands used in calculating these two indices. The WVWI used both of the Blue and NIR bands, whereas the NDWI used the green and the NIR bands. As mentioned before, much scattering happens in the blue range of spectrum than that in the green range. Accordingly, little reflectance in that blue range could be detected by the sensor, which makes it difficult to differentiate between the various LULC on the earth surface. 
Table (13)

Estimated water and non- water areas in Basra city center based on the WVWI index using Landsat 8 and Sentinel 2A images in 2018.

\begin{tabular}{|c|c|c|c|c|c|}
\hline \multirow{2}{*}{$\begin{array}{l}\text { Type of } \\
\text { Index }\end{array}$} & \multirow{2}{*}{$\begin{array}{l}\text { Land Use/ } \\
\text { Cover }\end{array}$} & \multicolumn{2}{|c|}{ Landsat 8} & \multicolumn{2}{|c|}{ Sentinel 2A } \\
\hline & & $\begin{array}{l}\text { Area } \\
\left(\mathbf{k m}^{2}\right)\end{array}$ & $\%$ & $\begin{array}{l}\text { Area } \\
\left(\mathbf{k m}^{2}\right)\end{array}$ & $\%$ \\
\hline \multirow{3}{*}{ WVWI } & Water & 84.52 & 7.35 & 82.55 & 7.18 \\
\hline & Non-Water & 1065.65 & 92.65 & 1067.62 & 92.82 \\
\hline & Total & 1150.17 & 100.00 & 1150.17 & 100.00 \\
\hline \multirow{3}{*}{ NDWI } & Water & 146.59 & 12.75 & 136.75 & 11.89 \\
\hline & Non-Water & 1003.58 & 87.25 & 1013.42 & 88.11 \\
\hline & Total & 1150.17 & 100.00 & 1150.17 & 100.00 \\
\hline
\end{tabular}

Accuracy assessment was also carried out on the water and non-water area derived from the WVWI and NDWI indices on both Landsat and Sentinel 2A data as shown in Table 14. It was found that the accuracy parameters for water areas derived from Sentinel data were higher than those derived from Landsat data. This also could be attributed to the higher spatial resolution of Sentinel 2A data $(10 \mathrm{~m})$ when compared with the spatial resolution of Landsat 8 data $(30 \mathrm{~m})$.It was also found that water areas extracted by using the NDWI index was more accurate than these obtained from using the WVWI index. This could be contributed to the scattering of electromagnetic radiation in the blue range of spectrum, which makes it difficult to well distinguish water areas from the other land uses and/or covers.

Table 14.

Accuracy assessment parameters for water areas derived from both

\begin{tabular}{|c|c|c|c|c|c|c|c|c|}
\hline \multirow{2}{*}{$\begin{array}{l}\mathrm{LU} / \mathrm{LC} \\
\text { classes }\end{array}$} & \multicolumn{4}{|c|}{ Sentinel 2A } & \multicolumn{4}{|c|}{ Landsat 8} \\
\hline & UA & $\mathrm{PA}$ & $\mathrm{OA}$ & $\mathrm{KC}$ & UA & PA & $\mathrm{OA}$ & $\mathrm{KC}$ \\
\hline WVWI & 80.00 & 83.08 & 81.78 & 0.79 & 76.67 & 82.80 & 75.52 & 0.78 \\
\hline NDWI & 87.09 & 97.09 & 88.51 & 0.85 & 85.50 & 86.25 & 84.11 & 0.83 \\
\hline
\end{tabular}
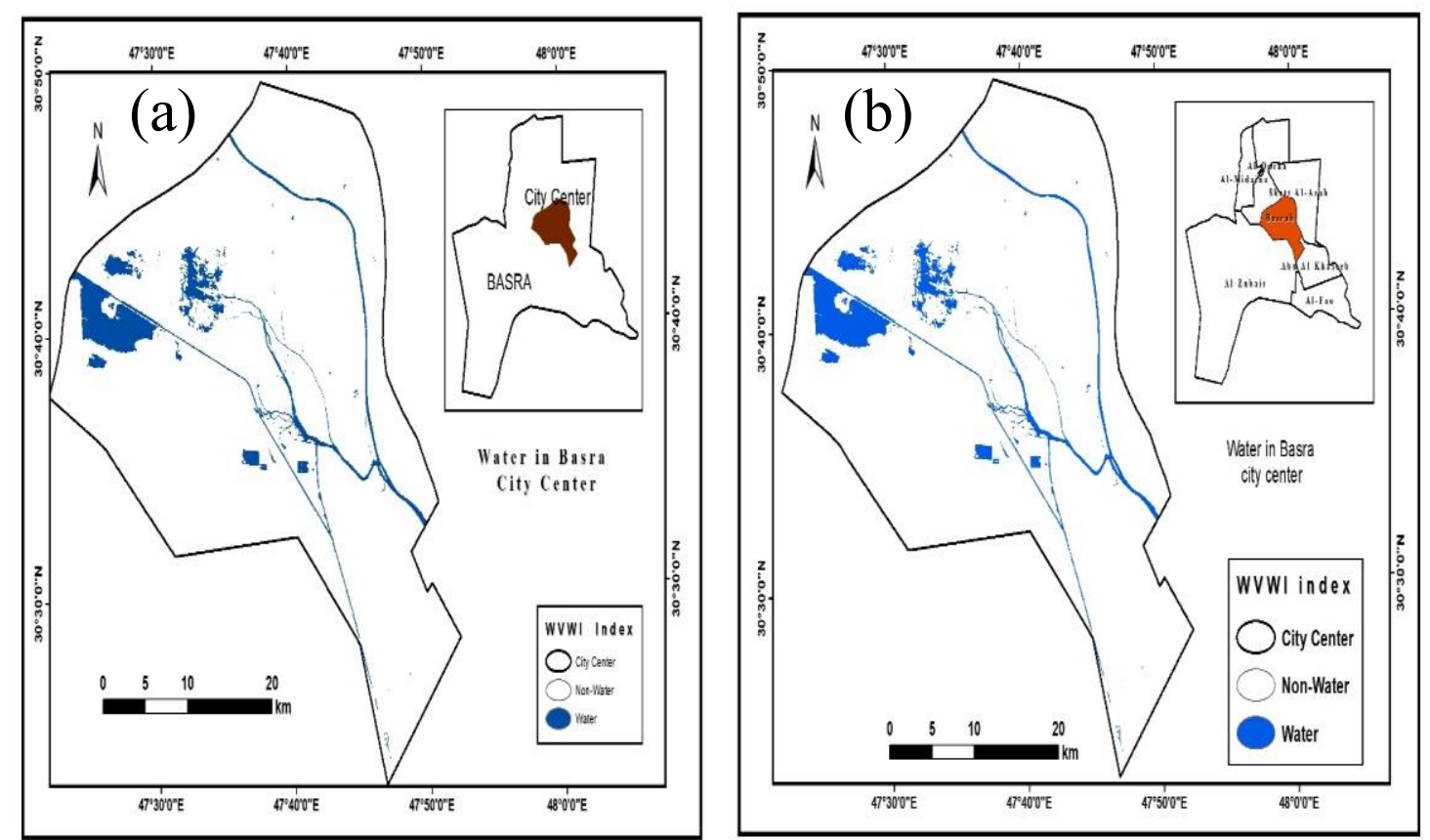

Figure (10): Spatial distribution of water lands in Basra city center using the WVWI index with both a) Landsat 8 and b) Sentinel $2 \mathrm{~A}$ images.
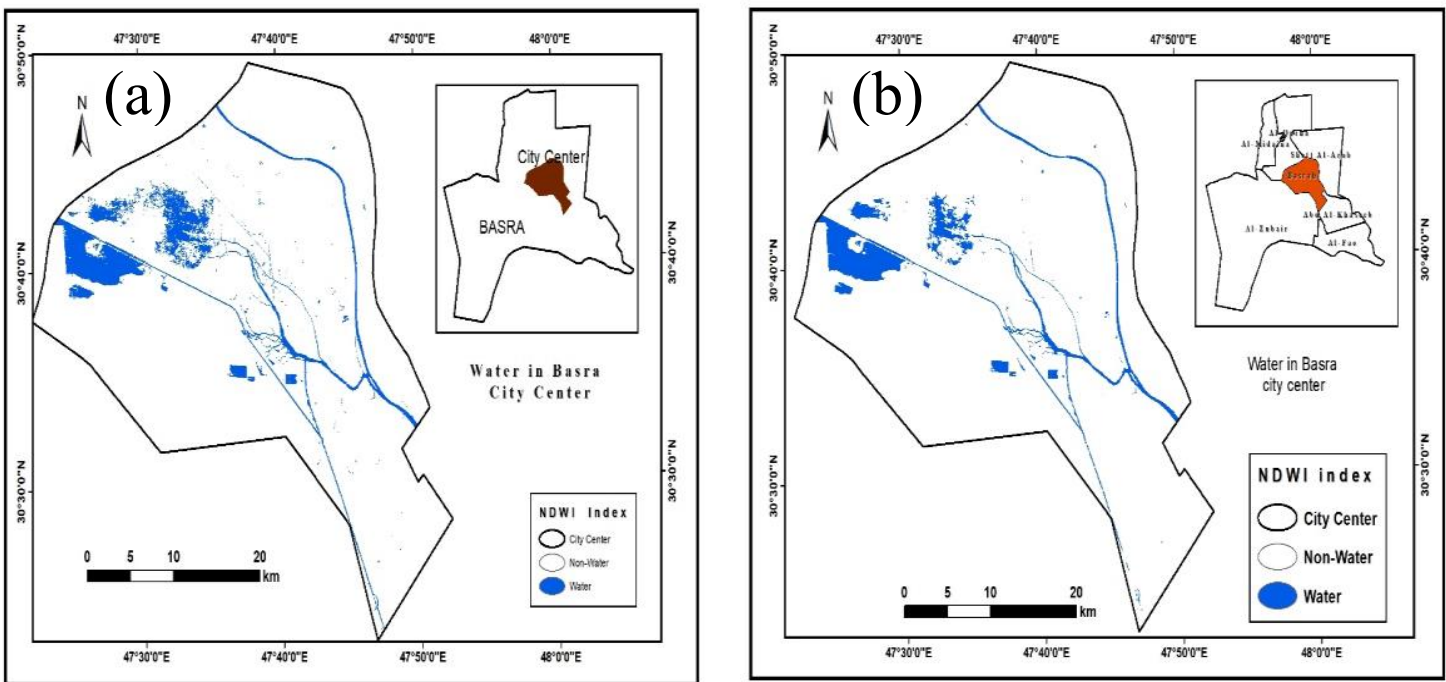

Figure (11): Spatial distribution of water lands in Basra city center using the NDWI index with both a) Landsat 8 and b) Sentinel $2 \mathrm{~A}$ images. 


\section{Urban areas in Basra City:}

There were wide differences in urban areas between these images by using supervised classification. Due to the similarity between urban and barren lands, where the higher the spatial resolution of the image, the less interfere between its constituent categories and thus the smaller the area of urban areas, LST can also be used as an indirect and slightly accurate method for estimating urban areas. The normalized difference of built-up index (NDBI) wasn't used in extracting

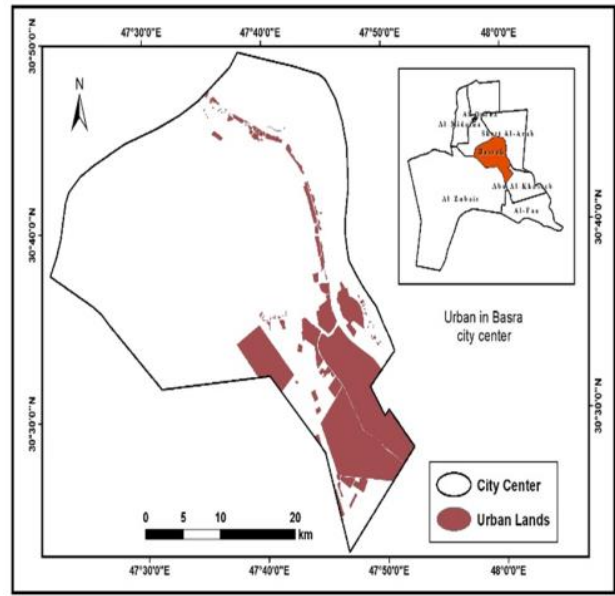

Figure (12): Spatial distribution of urban areas in Basra city center using Sentinel 2A images.

\section{Conclusion}

It can be concluded that the application of remotely sensed data and its techniques can provide more accurate results about LU/LC in Al-Basra city. The areas of LU/LC in AlBasra city is in the following order:

1. Barren land> Urban areas> Agricultural lands> water bodies.

2. Classification method by using the minimum distance technique had the highest accuracy in identifying LU/LC within the studied area (86.61). It was also found that the higher resolution images indicated the higher accuracy of the obtained results $(86.61,79.31,78.65)$.

3. The applied spectral indices were more accurate when compared with the classification methods in identifying agricultural lands and water bodies. The SAVI was more accurate (87.67) than the NDVI (88.11) in detecting agricultural lands. Also, The NDWI (88.51) was more accurate than the WVWI (81.78) in detecting water bodies within the area.

4. The LST can be used as an indirect and fairly accurate method for evaluating LULC in Al-Basra city. The accuracy of detecting urban areas wasn't high, where there is higher inclusion between urban areas and barren lands due to the similarity in their spectral reflectance. Consequently, the manual digitization of these areas is highly recommended. urban areas from the studied images. This is due to the similarity in spectral signature between urban areas and barren lands, which results in lots of inclusion between these two classes. Therefore, urban areas were manually digitized in this work from the Sentinel 2A image in 2018, which has a higher spatial resolution when compared with the Landsat 8 image. Urban areas in Basra city were about $196.33 \mathrm{~km}^{2}$ (17.07\%). The spatial distribution of urban areas in Basra City is illustrated in Figure 12. and figure 13.

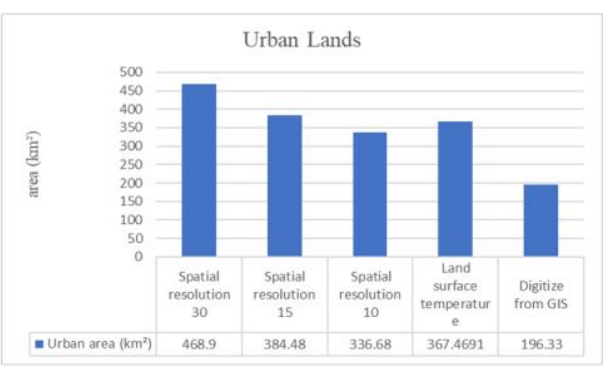

Figure (13): The result of area for different classification method for Basra city in 2018.

\section{RECOMMENDATIONS.}

1. Use the minimum distance technique to perform supervised classification of (LULC) detection.

2. SAVI is preferred to classify vegetation lands in Basra city.

3. It is preferable to use NDWI to calculate the amount of water bodies in Basra city.

4. LST can be used as an indirect for evaluating LULC in Basra city.

\section{References}

[1] El-Mewafi M, Zarzoura,F., and kandil, W., (2019). "Role of Land Use and Change Detection Techniques in Sustainability in Kafr El Sheikh Governorate at thern of Egypt by using Remote Sensing Data." International Journal of Scientific \& Engineering Research Volume 10, Issue 8, August-2019, ISSN 2229-5518.

[2] Friedl, M.A. and Brodley, C.E. (1997). Decision Tree Classification of Land Cover from Remotely Sensed Data. Remote Sensing of Environment, 61: 399-409. http://dx.doi.org/10.1016/S00344257(97)00049-7.

[3] Lambin, E.F., Baulies, X., Bockstael, N., Fischer, G., Krug, T., Leemans, R., Moran, E.F., Rindfuss, R.R., Sato, Y., Skole, D., Turner II, B.L. and Vogel, C. (1999). Land-Use and Land-Cover Change (LUCC) Implementation Strategy, USA.

[4] Zhang, Z., Wang, X., Zhao, X., Liu, B., Yi, L., Zuo, L., Wen, Q., Liu, F., $\mathrm{Xu}, \mathrm{J}$. and Hu, S. (2014). A2010 Update of National Land Use/Cover Database of China at 1:100000 Scale Using Medium Spatial Resolution Satellite Images. Remote Sensing of Environment, 149: 142-154. http://dx.doi.org/10.1016/j.rse.2014.04.004.

[5] Jog, S., \& Dixit, M. (2016, June). Supervised classification of satellite images. In 2016 Conference on Advances in Signal Processing (CASP) (pp. 93-98). 
[6] Rouse, J. W., Haas R.H., Schell J.A., and Deering D.W. (1973). Monitoring vegetation systems in the great plains with ERTS, Third ERTS symposium, NASA SP-351 I. pp 309-317.

[7] Huete, A.R. (1988). A Soil-adjusted vegetation index (SAVI). Journal remote sensing of environment, 25(3): 295-309.

[8] Stavrakoudis, D., Katsantonis, D., Kadoglidou, K., Kalaitzidis, A., \& Gitas, I. Z. (2019). Estimating Rice Agronomic Traits Using DroneCollected Multispectral Imagery. Remote Sensing, 11(5), 545.

[9] Mcfeeters, S.,K., (1996). "The use of the normalized difference water index (NDWI) in the delineation of open water features". Int. J. Remote Sens., 17 (7): 1425-1432. of environment, 113, 2606-2617.

[10] Wolf, A. F. (2012). "Using Worldview-2 Vis-NIR multispectral imagery to support land mapping and feature extraction using normalized difference index ratios". In SPIE Defense, Security, and Sensing (pp.83900N-83900N). International Society for Optics and Photonics.

[11] Zha, Y., Gao, J., \& Ni, S. (2003). Use of normalized difference built-up index in automatically mapping urban areas from TM imagery. International journal of remote sensing, 24(3), 583-594.

[12] Khalil, H. H., \& Hassaan, M. (2020). Semi-Automated Method to Extract Urban Areas from Barren Land/Bare Soil, Case Study: Idku, Nile Delta Coast, Egypt. CURRENT APPLIED SCIENCE AND TECHNOLOGY, 20(1), 90-105.

[13] Voogt, J A. and Oke, T.R., 2003. Thermal remote sensing of urban climates. Remote sensing of environment, 86, 370-384.

[14] Amiri, R., Weng, Q., Alimohammadi, A., \& Alavipanah, S. K. (2009). Spatial-temporal dynamics of land surface temperature in relation to fractional vegetation cover and land use/cover in the Tabriz urban area, Iran. Remote sensing of environment, 113(12), 2606-2617.

[15] Davis, S. M., Landgrebe, D. A., Phillips, T. L., Swain, P. H., Hoffer, R. M., Lindenlaub, J. C., \& Silva, L. F. (1978). Remote sensing: the quantitative approach. mhi.

[16] Hord, R. M. (1982). Digital image processing of remotely sensed data. Elsevier.

[17] Avdan, U., \& Jovanovska, G. (2016). Algorithm for automated mapping of land surface temperature using LANDSAT 8 satellite data. Journal of Sensors, 2016.
[18] Enoguanbhor, E. C., Gollnow, F., Nielsen, J. O., Lakes, T., \& Walker, B. B. (2019). Land cover change in the Abuja City-region, Nigeria: Integrating GIS and remotely sensed data to support land use planning. Sustainability, 11(5), 1313.

\section{Title Arabic:}

دراسة مقارنة لتقنيات الاستشعار عن بعد المختلفة لتقييم استخدام / الغطاء الأراضي في مدينة البصرة، العراق.

\section{Arabic Abstract:}

تعتبر محافظة البصرة من أهم محافظات العراق حيث تعتبر الميناء البحري الوحيد

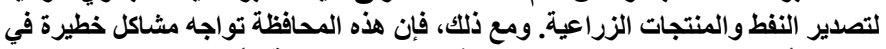

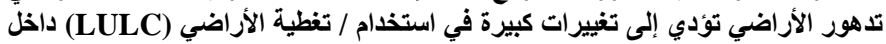

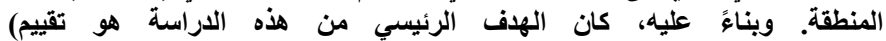

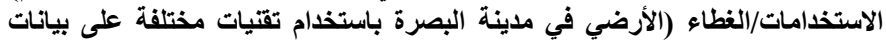

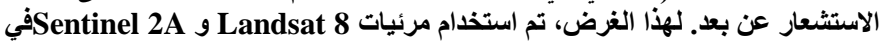

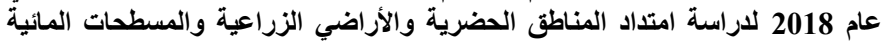

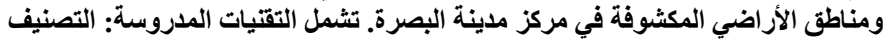

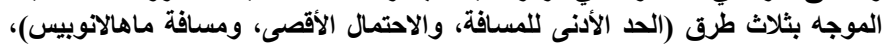

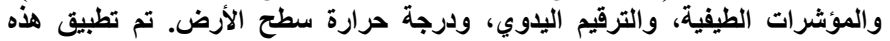

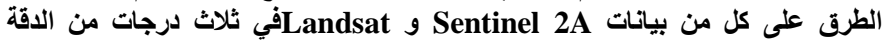

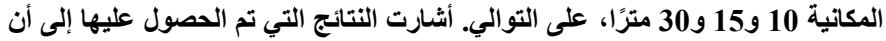

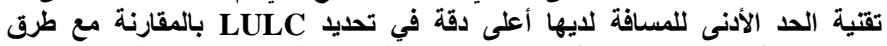

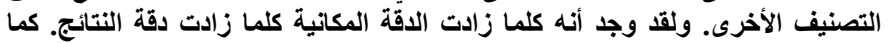

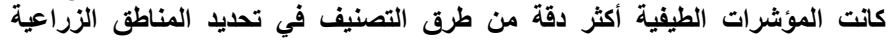

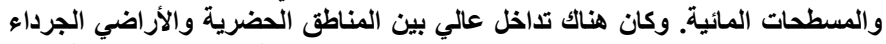

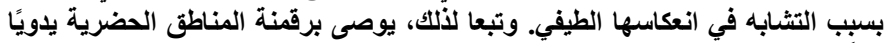

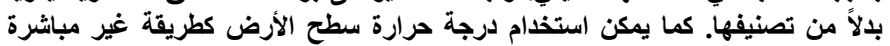

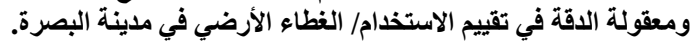

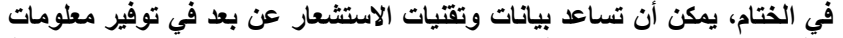

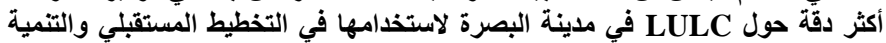
المستدامة . 